\title{
EFFECTS OF IRON SUPPLEMENTATION ON SERUM HEPCIDIN IN LOW BIRTH WEIGHT
} INFANTS

\author{
S.K. Berglund ${ }^{1}$, B. Lönnerdal ${ }^{2}$, B. Westrup ${ }^{3}$, M. Domellöf ${ }^{1}$
}

${ }^{1}$ Department of Clinical Sciences, Division of Pediatrics, Umeå University, Umeå, Sweden, ${ }^{2}$ Department of Nutrition, University of California, Davis, CA, USA, ${ }^{3}$ Department of Women and Child Health, Division of Neonatology, Karolinska Institute, Stockholm, Sweden

Background and aims: The iron regulatory hormone hepcidin has not been studied in infants, who experience large physiological changes in iron status. The objective was to study hepcidin and its correlation to iron status in iron-replete and iron-deficient low birth weight (LBW) infants, a group at particular risk of iron deficiency (ID).

Methods: We randomized 285 healthy LBW infants to receive three different levels of iron supplements; 0 (Placebo), 1, or $2 \mathrm{mg} / \mathrm{kg} /$ day, from 6 weeks to 6 months of age. Hepcidin, $\mathrm{Hb}$, and six variables of iron status were analyzed.

Result: Serum hepcidin did not change over time in the placebo group, despite a rapid decrease in serum ferritin. In iron supplemented infants, hepcidin increased significantly, reaching a mean (SD) concentration of $19.2(2.5) \mathrm{ng} / \mathrm{mL}$ in the $2 \mathrm{mg} / \mathrm{kg}$ /day-group vs $13.0(2.6) \mathrm{ng} / \mathrm{mL}$ in the placebo group at 6 months $(\mathrm{p}<$ $.001)$.

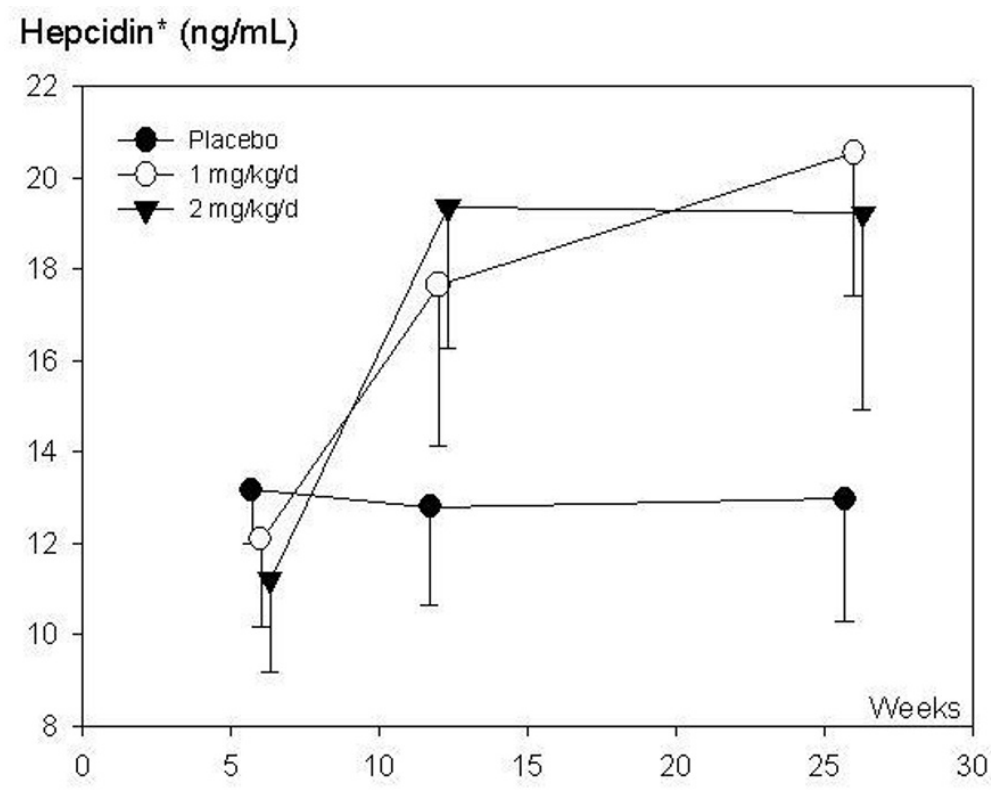

[Hepcidin responce to iron supplements]

The difference was even larger between iron-deficient infants and iron-replete infants at 6 mo (7.0 (2.9) $\mathrm{ng} / \mathrm{mL}$ vs $21.6(2.4) \mathrm{ng} / \mathrm{mL})$. Hepcidin was independently correlated to ferritin and transferrin receptor concentration at $6 \mathrm{wk}$, ferritin alone at $12 \mathrm{wk}$, and to ferritin, transferrin, and $\mathrm{Hb}$ at $6 \mathrm{mo}$.

Conclusions: Hepcidin is closely associated with iron status and may be a useful indicator of iron stores in infants, possibly less age dependent than ferritin. 